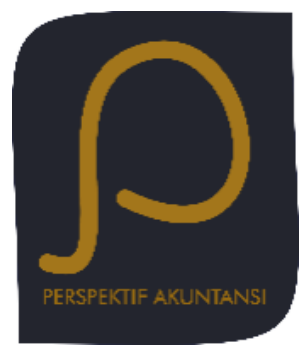

Perspektif Akuntansi

Volume 1 Nomor 1 (Oktober 2018), hal. 39-52

ISSN: 2623-0194(Print), 2623-0186(Online) Copyright $(\mathrm{C}$ The Authors(s). All Rights Reserved

Fakultas Ekonomika dan Bisnis, Universitas Kristen Satya Wacana

DOI: https://doi.org/10.24246/persi.v1i1.p39-52

http://ejournal.uksw.edu/persi

\title{
Determinan Kinerja Sistem Informasi: Persepsi Pengguna Software Akuntansi
}

\author{
Ika Kristianti ${ }^{1}$ \\ Universitas Kristen Satya Wacana
}

Received Abstract. The purpose of this research is to examine the influence of the 21/05/2018 quality of the information system of the quality of service on the MYOB application, to test the influence of the quality of the information system

Accepted on performance of system applications $M Y O B$, and to test the quality of

26/06/2018 the services against kinerja sistem on applications MYOB. The object of this research i.e. MYOB software. Sample collection using a purposive sampling. Data acquisition as much as 219 respondents. Data processing using Structural Equation models. The results of this research show that the quality of system information significantly negative effect on quality of service, the quality of the system of information and quality of service on performance the system shows no results significantly.

Keywords: $M Y O B$, service quality, system quality, work performance

\begin{abstract}
Abstrak. Tujuan dari penelitian ini untuk menguji pengaruh kualitas sistem informasi terhadap kualitas layanan pada aplikasi MYOB, untuk menguji pengaruh kualitas system informasi terhadap kinerja system aplikasi MYOB, dan untuk menguji kualitas layanan terhadap kinerja sistem pada aplikasi MYOB. Objek penelitian ini yaitu software MYOB. Teknik pengumpulan pengambilan sampel menggunakan purposive sampling. Perolehan sampel sebanyak 219 responden. Pengolahan data menggunakan Structural Equation Model. Hasil penelitian ini menunjukkan bahwa kualitas system informasi berpengaruh negatif dan signifikan terhadap kualitas layanan, kualitas system informasi dan kualitas layanan terhadap kinerja sistem menunjukkan hasil tidak berhubungan secara signifikan.
\end{abstract}

Kata kunci: MYOB, kualitas system informasi, kualitas layanan, kinerja system

1 ika.kristianti@staff.uksw.edu 


\section{Pendahuluan}

Teknologi informasi secara umum, dan internet secara khusus memiliki dampak besar bagi kegiatan operasional entitas bisnis (Delone \& McLean, 2003). Perkembangan teknologi informasi dan system informasi akan membantu manajemen dalam proses pengambilan keputusan (Chang, Chen, \& Lan, 2012). Peningkatan kualitas pengambilan keputusan oleh manajemen menjadi gerbang awal dalam kebangkitan perusahaan. Salah satu program akuntansi sebagai alat bantu bagi pimpinan perusahaan dalam membuat keputusan terkait kegiatan operasional perusahaan. Program akuntansi yang banyak digunakan perusahaan adalah Mind Your Own Business, atau lebih dikenal MYOB.

Beberapa studi menunjukkan bahwa MYOB banyak digunakan di berbagai perusahaan, dari mulai skala kecil sampai dengan perusahaan dengan skala besar. Faktor utama penyebabnya adalah tingkat kemudahan dari progam MYOB (user friendly), berikutnya adalah kemampuan untuk export data ke program excel. Santamour (2011) menyatakan bahwa MYOB merupakan program yang sederhana namun lengkap. Lombardo (2002) menunjukkan survei bahwa MYOB merupakan salah satu software akuntansi terbaik yang digunakan untuk ekspansi perusahaan. Hal ini disebabkan MYOB banyak digunakan di berbagai negara. Sebelumnya survei Lombardo (2005) menunjukkan bahwa MYOB mampu menjangkau akuntan perusahaan dalam upaya internal audit karena aspek kemudahannya. Dibandingkan dengan software akuntansi lainnya. Informasi ini juga ditunjang dengan survei dari Hedtke (2005) yang menunjukkan bahwa MYOB merupakan salah satu dari 5 program akuntansi yang banyak digunakan oleh perusahaan level menengah kebawah. Hal ini disebabkan karena faktor kemudahan (user friendly), harga yang relatif murah, dan pemberian versi trial untuk memberikan kenyamanan bagi konsumen yang akan melakukan uji coba program.

Semua hal terkait dengan MYOB diatas menunjukkan informasi mengenai keberhasilan sistem informasi di dalam meningkatan kinerja perusahaan. MYOB dikembangkan DeLone dan McLean tahun 1992 dan beberapa penelitian 
sering disebut IS success model. Banyak penelitian sebelumnya yang berusaha mengembangkan model DeLone \& McLean 1992. DeLone \& McLean (2003) merevisi dan mengembangkan model tersebut dengan penambahan konstruk baru, yaitu kualitas layanan dan kombinasi efek model secara individu maupun organisasi.

Penelitian ini bertujuan untuk menguji konsistensi model DeLone\& McLean (2003) mengenai kesuksesan sistem informasi yang sudah berjalan 1 dekade, dan membuktikan dampaknya terhadap kinerja perusahaan. Jika terjadi konsistensi maka akan semakin memperkuat penggunaan IS success model DeLone \& McLean (2003) untuk berbagai level pengguna, dari dasar sampai advance. Penelitian ini merupakan pengembangan dari penelitian Myers, Kappelman, \& Prybutok (1997), Rai, Lang, \& Welker (2002), dan Chang, Chen, $\&$ Lan (2012). Perbedaan yang terjadi dalam penelitian ini terletak pada level pengguna, yang ditunjukkan oleh kesuksesan sistem informasi akan dilihat dari responden mahasiswa, yang merupakan pengguna dengan level dasar

\section{Telaah Pustaka}

\section{IS Sucess Model}

DeLOne \& McLean (1992) mengembangkan model yang disebut dengan mode kesuksesan system informasi DeLone\& Maclean. Model yang diusulkan ini merefleksi ketergantungan dari enam pengukuran kesuksesan system informasi. Keenam elemen dari model ini: kualitas system, kualitas informasi, penggunaan, kepuasan pemakai, dampak individual, dan dampak organisasi. Model kesuksesan ini didasarkan pada proses dan hubungan kausal dari dimensi-dimensi di model. Perubahan model yang dikembangkan DeLone \& McLean (1992) ke tahun 2003 terletak pada revisi model, dengan adanya penambahan konstruk baru yaitu kualitas layanan. Model DeLone \& McLean tidak mengukur ke enam dimesi secara independen, namun mengukur secara keseluruhan satu mempengaruhi lainnya.

Suatu system terdiri dari beberapa proses yang saling mempengaruhi, misalnya semakin tinggi kualitas system diharapkan akan menyebabkan kepuasan 
pemakai dan pengguna yang lebih tinggi, yang selanjutnya akan mempengaruhi secara positif produktivitas, dengan hasil peningkatan produktivitas organisasional (Mariana, 2006). Model ini akan menjelaskan arah hubungan antar elemen menyebabkan pengaruh positif atau negatif.

\section{Pengembangan Hipotesis}

\section{Pengaruh kualitas system terhadap kualitas layanan}

Dimensi pengukuran konstruk kualitas layanan terbagi dalam berbagai aspek, seperti tangibility, reliability, responsiveness, assurance, dan emphaty (Parasuraman, Zeithhaml, \& Berry, 1988). Dalam penelitiannya, Li, Tan, \& Xie (2002) menyarankan faktor keahlian teknis personalia di bidang IT dan pemberian pelatihan kepada pengguna untuk meningkatkan kualitas layanan. Penelitian lainnya, DeLone \& McLean (1992) yang mengembangkan 18 indikator pengukuran dari 100 penelitian terkait dengan kualitas sistem. Sedangkan McKinney, Yoon, \& Zahedi (2002) membagi kualitas sistem kedalam empat aspek: accessability, usability, navigation, dan interactivity. Semua aspek tersebut terbukti berpengaruh terhadap kualitas layanan. Penelitian-penelitian tersebut dikuatkan oleh Keating, Rugimbana, \& Quazi (2003) dengan efisiensi dan efektivitas sistem yang mempengaruhi kualitas layanan. Berdasarkan hasil pengujian peneliti-peneliti sebelumnya, maka dapat dirumuskan hipotesis pertamapenelitian ini:

$\mathrm{H}_{1}$ : Kualitas sistem berpengaruh signifikan terhadap kualitas layanan.

\section{Pengaruh kualitas system terhadap kinerja system}

Penelitian Chang, Chen, \& Lan (2012) menyatakan kinerja sistem dibagi menjadi dua konstruk, yaitu work performance dan organizational commitment. Work performance mengacu kepada hasil dan capaian yang bisa diperoleh oleh masing-masing karyawan (secara individu) dalam pekerjaannya. Keberhasilan dari karyawan ini disebabkan oleh dua faktor, yaitu faktor personal (pengetahuan, keahlian, kapabilitas, motivasi, attitude) dan faktor teknis (interaksi dengan atasan, encouragement, reward). Tax \& Bowen (2006) menguatkan pendapat ini dengan pernyataan bahwa performance terkait 
dengan bagaimana cara organisasi mencapai tujuannya. Kualitas sistem sendiri merupakan pengukuran terhadap kemampuan sistem informasi dalam menangani error, konsistensi pelaporan, kemudahan penggunaan, dan output dokumentasi. Sehingga DeLone \& McLean (2003) memiliki pendapat dan berhasil dibuktikan bahwa kualitas sistem informasi yang baik akan memberikan dampak simultan terhadap kepuasan penggunanya dan kinerja secara individual. Dampak ini yang akan memberikan pengaruh secara langsung terhadap kinerja organisasi. Berdasarkan hasil dari peneliti-peneliti tersebut, maka dapat disimpulkan hipotesis kedua dalam penelitian ini:

$\mathrm{H}_{2}$ : Kualitas sistem informasi berpengaruh positif terhadap kinerja sistem

\section{Pengaruh kualitas layanan terhadap kinerja sistem}

Konsep kualitas layanan yang dijelaskan Chang, Chen, \& Lan (2012), disederhanakan oleh Rai, Lang, \& Welker (2002) dengan merujuk langsung bahwa tujuan organisasi yang baik akan memberikan pelanggan kepuasan dalam layanan sehingga multiple process akan terjadi. Multiple process yang terjadi disini merupakan perpaduan kualitas layanan yang diberikan organisasi kepada pelanggan, maupun efek layanan yang direspon oleh pelanggan terhadap organisasi. Konsep kualitas layanan sendiri ditekankan oleh Rai, Lang, \& Welker (2002) kepada sistem informasi sejak sistem informasi banyak digunakan untuk proses pemasaran produk. Parasuraman, Zeithhaml, \& Berry (1988) memberikan perhatian khusus mengenai kualitas layanan, yang menunjukkan ada perbedaan (gap) antara ekpektasi layanan dan persepsi layanan. Gap inilah yang harus dijembatani oleh organisasi dengan cara komunikasi (word of mouth), pengalaman pemasaran, dan survei kebutuhan pelanggan (Pitt, Watson, \& Kavan, 1995; Chang, Chen, \& Lan, 2012). Septianita, Agus Winarno, \& Arif (2014) menyatakan ketika kualitas sistem yang digunakan semakin baik, maka kepuasan atas kinerja sistem meningkat. Dengan hasil penelitian DeLone \& McLean (2003) serta Myers, Kappelman, \& Prybutok (1997) yang membuktikan bahwa salah satu faktor keberhasilan 
sistem informasi adalah kualitas layanan, maka dirumuskan hipotesis ketiga penelitian ini:

$\mathrm{H}_{3}$ : Kualitas layanan berpengaruh positif terhadap kinerja sistem.

\section{Metoda}

Responden menggunakan mahasiswa S1 prodi akuntansi FEB UKSW, yang mengambil mata kuliah komputer akuntansi pada semester ganjil 2016/2017, atau sudah pernah menggunakan program My Own Bussiness (MYOB). Kuesioner yang telah tersebar sebanyak 250 lembar, jumlah yang kembali sebanyak 219 kuesioner sehingga response rate dari penyebaran kuesioner mencapai $88 \%$ dari total kuesioner yang disebar.

Tabel 1. Rekapitulasi Responden.

\begin{tabular}{lcc}
\hline & Jumlah & Presentase \\
\hline Total kuesioner yang disebar & 250 & $100 \%$ \\
Kuesioner kembali & 219 & $88 \%$ \\
\hline
\end{tabular}

Dari kuesioner yang kembali diketahui bahwa 58\% responden berjenis kelamin perempuan dan $42 \%$ berjenis kelamin laki-laki. Responden mahasiswa yang sedang berada dalam semester 4 mendominasi dengan jumlah 104 orang, semester 6 sebanyak 65 orang, dan sisanya sebanyak 50 orang merupakan mahasiswa dari semester lain. Dari seluruh kuesioner yang kembali, responden merupakan mahasiswa yang sudah pernah menggunakan MYOB dalam keseharian mereka, dengan intensitas penggunaan selama 1-3 kali seminggu. Penelitian ini adalah penelitian kuantitatif yang menggunakan instrumen berupa kuesioner. Kuesioner diadopsi dari penelitian Chang, Chen, \& Lan (2012) dengan modifikasi penghilangan pada konstruk job satisfaction. Konstruk job satisfaction ini dihilangkan karena terkait dengan sampel responden yang akan digunakan, yaitu mahasiswa. Mahasiswa diasumsikan tidak memiliki pengalaman kerja yang memadai dengan software yang akan diuji kualitas dan kinerjanya. Berdasarkan hipotesis yang sudah dibuat dalam penelitian ini (H1, H2, dan H3), maka penelitian ini merancang model seperti pada Gambar 1 berikut. Konstruk yang digunakan dalam penelitian ini terdiri 
dari kualitas sistem, kualitas layanan, dan kinerja sistem yang diadopsi dari penelitian Chang, Chen, \& Lan (2012).

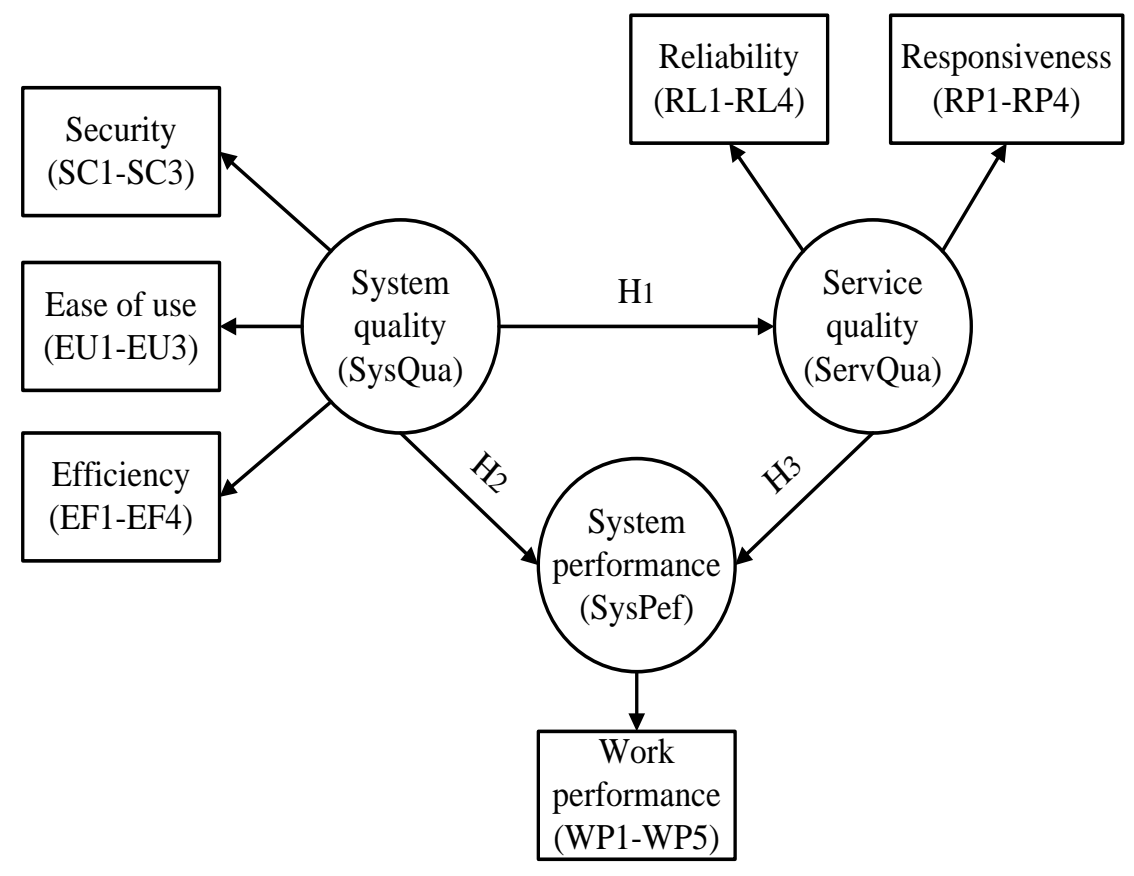

Gambar 1. Model penelitian

Konstruk kualitas sistem dibagi dalam tiga dimensi: security (kemampuan sistem dalam memberikan rasa aman, konfirmasi identifikasi bagi pengguna/ penyediaan password, dan pemasangan anti virus), ease of use (tampilan sistem, adanya tutorial dan instruksi penggunaan sistem, dan penjelasan dari setiap tools), dan efficiency (kemudahan dalam penggunaan, familiar, sistem bisa meningkatkan performa perusahaan, dan kecepatan pemrosesan data). Konstruk kualitas layanan dibagi dalam dua dimensi; reliabiliy (keterkaitan antar data, kepercayaan terhadap pemrosesan data, kemampuan sistem untuk meningkatkan performa perusahaan, dan kemampuan sistem untuk memuaskan pengguna) dan responsiveness (notifikasi kesalahan dalam pengoperasian sistem, kemampuan mendeteksi kesalahan, memberikan tutorial, dan saran dalam perbaikan kesalahan). Sedangkan kinerja sistem merupakan penjabaran langsung dari work performance system (sistem dapat meningkatkan performa pengguna, kemampuan dalam memperbaiki 
kesalahan, kemudahan dalam penggunaan tools dalam sistem, peningkatan efisiensi performa kinerja pengguna, dan peningkatan sistem evaluasi).

Model dalam penelitian merupakan structrual equation modelling (SEM). Peneliti akan melakukan pengujian dengan alat bantu LISREL 8.8 full version, karena terdapat lebih dari 15 indikator di dalam penelitian. Variabel laten di dalam penelitian terdiri dari tiga: kualitas sistem (SysQua), kualitas layanan (ServQua), dan kinerja sistem (SysPef). Variabel teramati dari penelitian ini terbagi dalam 6 dimensi. Untuk mengukur SysQua, terdapat 3 dimensi: security (SC1, SC2, SC3), ease of use (EU1, EU2, EU3), dan efficiency (EF1, EF2, EF3, EF4). Untuk mengukur ServQua, terdapat 2 dimensi: reliability (RL1, RL2, RL3, RL4) dan responsiveness (RP1, RP2, RP3, RP4). Sedangkan pengukuran SysPef berasal dari dimensi work performance (WP1, WP2, WP3, WP4, WP5). Semua variabel teramati dalam penelitian ini diukur dengan skala likert basis 5 , yang terdiri dari tingkatan sangat tidak setuju (STS), tidak setuju (TS), netral (N), setuju (S), dan sangat setuju (SS).

Pengujian model dilakukan dengan analisis SEM, yang terdiri dari tiga tahapan: uji kecocokan model pengukuran, uji kecocokan model secara keseluruhan dan uji kecocokan model structural. Uji kecocokan model pengukuran dilakukan untuk memvalidasi reliabilitas dari konstruk. Sedangkan Uji kecocokan model secara keseluruhan dilakukan dengan hasil output goodness of fit hasil dari LISREL, dengan kriteria pengujian absolute dan incremental (Kristanto, 2011). Pengujian yang terakhir, uji kecocokan model struktural, digunakan untuk melihat arah dan signifikansi hubungan antar konstruk atau disebut pengujian hipotesis.

\section{Hasil dan Pembahasan}

\section{Uji Validitas dan Reabilitas Instrumen}

Pengujian kecocokan model pengukuran dengan cara yang serupa pada uji yang terpakai untuk program, yaitu menggunakan uji reliabilitas dan validitas. Semakin tinggi validitas suatu variabel maka pengujian tersebut semakin sesuaid dengan sasaran atau tujuannya (Kristanto, 2011). Uji validitas yang 
merupakan pengujian terhadap 22 pertanyaan pada kuesioner yang tersebar. Dari hasil pengujian terdapat pernyataan yang tidak valid yaitu pertanyaan EU1, EU3, EF4 yang mengukur SysQua, RP1, RP2, RP3, RP4 yang mengukur validitas pertanyaan SerQua. Dari Tabel 2 terlihat bahwa nilai $t$-value lebih besar dari 1.96, sehingga dapat disimpulkan bahwa indikator-indikator dalam penelitian ini valid.

Berdasarkan pengolahan data yang telah dilakukan dengan menggunakan program, diperoleh hasil validitas sebagai berikut:

Tabel 2. Hasil Validitas Konstruk Model

\begin{tabular}{clcc}
\hline Indikator & \multicolumn{1}{c}{ Keterangan Indikator } & t-value & Keterangan \\
\hline SC1 & Keamanan sistem & 3.64 & Valid \\
SC2 & Ketersediaan password & 5.47 & Valid \\
EU2 & Tutorial sistem & 3.96 & Valid \\
EF1 & Kemudahan penggunaan & 3.73 & Valid \\
EF2 & Peningkatan performa kinerja & -2.68 & Valid \\
EF3 & Kepuasan pengguna & -5.44 & Valid \\
RL1 & Keterkaitan data & 3.50 & Valid \\
RL2 & Kepercayaan pemrosesan data & 4.31 & Valid \\
RL3 & Peningkatan performa kinerja perusahaan & 3.70 & Valid \\
RL4 & Kepuasan pengguna sistem & 3.17 & Valid \\
WP1 & Peningkatan performa pengguna & 4.67 & Valid \\
WP2 & Kemampuan memperbaiki kesalahan & 5.01 & Valid \\
WP3 & Kemudahan penggunaan & 5.01 & Valid \\
WP4 & Efisiensi kinerja pengguna & 4.62 & Valid \\
WP5 & Sistem evaluasi & 4.67 & Valid \\
\hline
\end{tabular}

Uji reliabilitas dapat terhitung dengan variance extracted dari masing-masing variabel teramati dengan criteria nilai yang lebih besar dari 0,50. Nilai tersebut diambil dari angka-angka yang ada pada output Completely Standarized Solution dari hasil pengolahan data. Dari data yang telah dikumpulkan, telah dilakukan uji reliabilitas untuk menguji apakah sudah cukup andal untuk dijadikan alat ukur. Hasil perhitungan variable reliability dapat dilihat pada tabel berikut:

Tabel 3. Hasil Reliabilitas Variabel

\begin{tabular}{llll}
\hline Variabel & Jumlah Indikator & Reliabilitas & Keterangan \\
\hline
\end{tabular}




\begin{tabular}{clll}
\hline Kualitas sistem & 6 & 0.60 & Reliabel \\
Kualitas layanan & 4 & 0.63 & Reliabel \\
Kinerja Sistem & 5 & 0.75 & Reliabel \\
\hline
\end{tabular}

\section{Hasil Uji Kecocokan Model Keseluruhan}

Pengujian kecocokan model secara keseluruhan untuk kinerja MYOB dilakukan dengan cara melihat hasil analisisnya menggunakan alat uji LISREL, yang terlihat pada ukuran Goodness of Fit. Hasil dari uji ini dapat terlihat bahwa secara umum kecocokan model menunjukkan hasil baik. Nilai dari ukuranukuran Goodness of Fit Statistic untuk kinerja MYOB dapat dilihat sebagai berikut:

Tabel 4. Hasil Kecocokan Model Keseluruhan

\begin{tabular}{|c|c|c|c|}
\hline Kriteria & \multicolumn{2}{|c|}{ Hasil Estimasi } & Kesimpulan \\
\hline RMSEA & 0,047 & & Baik \\
\hline \multirow[t]{2}{*}{ ECVI } & $M^{*}: 0,91$ & $2,86 \mathrm{l}^{* * *}$ & Baik \\
\hline & $\mathrm{S}^{* *}: 1,10$ & & \\
\hline \multirow[t]{2}{*}{ AIC } & $M^{*}: 197,33$ & $622,81 \mathrm{l}^{* * *}$ & Baik \\
\hline & $S^{* *}: 240,00$ & & \\
\hline \multirow[t]{2}{*}{ CAIC } & $M^{*}: 368,50$ & $766,69 \mathrm{l}^{* * *}$ & Baik \\
\hline & $S^{* *}: 766,69$ & & \\
\hline NFI & 0,80 & & Cukup Baik \\
\hline NNFI & 0,90 & & Baik \\
\hline CFI & 0,92 & & Baik \\
\hline IFI & 0,93 & & Baik \\
\hline RFI & 0,74 & & Cukup Baik \\
\hline RMR & 0,066 & & Cukup Baik \\
\hline GFI & 0,93 & & Baik \\
\hline AGFI & 0,90 & & Baik \\
\hline
\end{tabular}

\section{Hasil Uji Kecocokan Model Struktural (Structural Model Fit)}

Menurut Wijayanto (2008), untuk menilai seberapa baik coefficient of determination dari persamaan structural, akan terlihat dari besaran $\mathrm{R}^{2} . \mathrm{R}^{2}$ terdapat dari hasil dari pengujian yang dapat terlihat pada Structural Equation. Model penelitian (Gambar 1) memiliki R² 0.17 yang berarti Kualitas layanan (ServQua) hanya menjelaskan $17 \%$ dari perubahan pada variabel laten Kualitas sistem (SysQua), sedangkan $\mathrm{R}^{2} 0.47$ yang berarti Kinerja sistem dan Kualitas 
sistem mampu menjelaskan $47 \%$ dari perubahan variabel laten Kualitas layanan (ServQua).

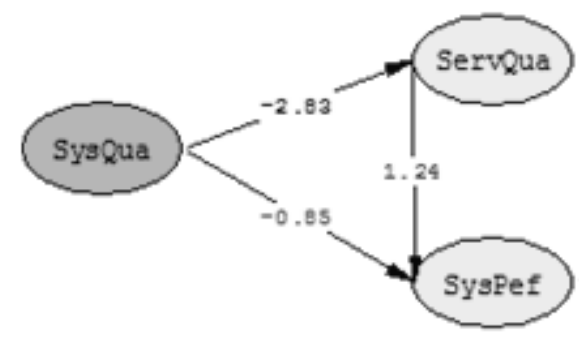

Gambar 2. Path Diagram Lisrel

Penelitian ini bertujuan untuk menguji pengaruh Kualitas sistem (SysQua) terhadap Kualitas layanan (ServQua) pada aplikasi MYOB, untuk menguji pengaruh Kualitas sistem (SysQua) terhadap Kinerja sistem (SysPef) aplikasi MYOB, dan untuk menguji Kualitas layanan (ServQua) terhadap Kinerja sistem (SysPef) pada aplikasi MYOB. Pada hasil uji kecocokan model structural (Structural Model Fit) menunjukkan bahwa Kualitas sistem (SysQua) berhubungan negative secara signifikan terhadap Kualitas layanan (ServQua) dilihat dari hasil pengujian dengan nilai t-test $-2,82$.

Pada hasil uji hipotesis pertama ditolak, karena dari hasil uji mengindikasikan bahwa kualitas sistem MYOB tidak akan berpengaruh pada kualitas layanan. Dari hasil uji ini, responden merasakan bahwa tidak ada keterkaitan antara kualitas sistem dengan kualitas layanan yang diberikan oleh MYOB. Hasil penelitian ini tidak sejalan dengan penelitian DeLone dan McLean (1992), Li, Tan, \& Xie, (2002), McKinney, Yoon, \& Zahedi, (2002), Keating, Rugimbana, \& Quazi, (2003), Chang, Chen, \& Lan, (2012).

Pada pengujian hipotesis kedua, yaitu kualitas sistem (SysQua) terhadap kinerja sistem (SysPef) diterima, namun tidak berpengaruh secara signifikan. Hasil pengujian menghasilkan nilai t-test 1,24, menunjukkan bahwa kualitas sistem akan mempengaruhi performa system. Sedangkan pada hipotesis terakhir mengenai hubungan kualitas layanan terhadap kinerja sistem mendapatkan hasil ditolak, namun juga menunjukkan tidak ada pengaruh yang 
signifikan. Dengan hasil pengujian sebesar -0.84 , hasil ini mengindikasikan bahwa tidak ada hubungan antara kualitas layanan dengan kinerja sistem.

Lebih jauh hasil uji hipotesis kedua mengindikasikan bahwa kualitas sistem MYOB yang baik, akan meningkatkan kemampuan dalam mengolah data pada sebuah sistem. Semakin meningkat performa sebuah system, maka kinerja pengguna juga akan meningkat. Peningkatan kinerja individu membuat perusahaan semakin meningkat daya saingnya. Kualitas sistem yang baik akan menjadi atribut yang bernilai bagi kinerja sistem, karena dengan kualitas pengolahan informasi yang baik bagi sistem, maka akan membuat kinerja sistem semakin meningkat. Hasil ini menguatkan penelitian DeLone dan McLean (2003), Tax \& Bowen, (2006), dan Chang, Chen, \& Lan, (2012).

Uji hipotesis ketiga, memberikan hasil ditolak untuk pengaruh kualitas layanan dengan kinerja sistem. Kepuasan pengguna menjadi salah satu tolok ukur dalam penilaian kualitas layanan. Ketika pengguna merasa tidak puas dengan kualitas sistem yang digunakan, maka kualitas layanan yang diberikan sistem akan rendah. Hasil penelitian ini tidak mendukung penelitian DeLone dan McLean (1992), Li, Tan, \& Xie, (2002), McKinney, Yoon, \& Zahedi, (2002), Keating, Rugimbana, \& Quazi, (2003), Chang, Chen, \& Lan, (2012), Septianita, Agus Winarno (2014).

\section{Simpulan}

Penelitian ini bertujuan untuk menguji pengaruh Kualitas sistem terhadap Kualitas layanan pada aplikasi MYOB, untuk menguji pengaruh Kualitas sistem terhadap Kinerja sistem aplikasi MYOB, dan untuk menguji kualitas layanan terhadap kinerja sistem pada aplikasi MYOB. Pada hasil uji kecocokan model structural menunjukkan bukti bahwa Kualitas sistem berpengaruh negative secara signifikan terhadap Kualitas layanan, sedangkan pada hipotesis kedua dan ketiga, yaitu pengujian Kualitas sistem terhadap Kinerja sistem, dan Kualitas layanan terhadap Kinerja sistem menunjukkan hasil tidak berhubungan secara signifikan. Dengan hasil penelitian ini, maka IS Success Model yang dikembangkan oleh DeLeon dan McLean kurang tepat jika 
digunakan untuk responden mahasiswa yang dapat dikategorikan sebagai pengguna dengan level dasar.

Dalam penelitian ini terdapat keterbatasan yaitu responden merupakan mahasiswa yang belum tentu menggunakan MYOB dalam keseharian mereka, Oleh karena itu, penelitian selanjutnya yang ingin melanjutkan penelitian ini: (1) dapat meneliti software lainnya, seperti Accurate, Quick Book, Office Accounting. (2) melibatkan kepada karyawan yang menggunakan aplikasi MYOB dalam keseharian pekerjaannya.

\section{Daftar Pustaka}

Chang, C., Chen, S., \& Lan, Y. (2012). Motivating medical information system performance by system quality, service quality, and job satisfaction for evidence-based practice. BMC Medical informatics and decision making, 12, 135-147.

Delone, W., \& McLean, E. (2003). The DeLone and McLean model of information systems sucess: a ten year update. Management Information Systems, 19, 9-30.

DeLone, W., \& McLean, R. (1992). Information Systems Success: The Quest for Dependent Variable. Information Systems Research, 3, 60-93.

Hedtke, J. (2005). Small Biz Software Gets Bigger. Accounting Technology, 21(28), 34.

Keating, B., Rugimbana, R., \& Quazi, A. (2003). Differentiating Between Service Quality and Relationship Quality In Cyberspace. Management Kualitas Layanan, 13, 217-232.

Kristanto, S. (2011). Structural Equation Modeling (SEM) Menggunakan MX dan LISREL. Publikasi internal UKRIDA.

Li, Y., Tan, K., \& Xie, M. (2002). Measuring Web Based Kualitas Layanan. Total Quality Management, 13, 685-700.

Lombardo, C. (2002). MYOB partners programs: Expanding services. Accounting Technology, 18(20).

Lombardo, C. (2005). MYOB: Reaching Accountants. Accounting Technology, 21(45), 25-32.

Mariana, N. (2006). Pengukur-pengukur Kesuksesan Sistem Informasi Eksekutif. Jurnal Dinamika Teknologi Informasi, XI, 30-37.

McKinney, V., Yoon, K., \& Zahedi, F. (2002). The Measurement of Web-Customer Satisfaction: An Expectation and Disconfirmation Approach. Information Systems Research, 13, 296-315.

Myers, B., Kappelman, L., \& Prybutok, V. (1997). A Comprehensive Model for Assessing the Quality and Productivity of The Information Systems Function: Toward a Theory for Information Systems Assessment. Information Research and Management Journal, 10, 6-25. 
Parasuraman, A., Zeithhaml, V., \& Berry, L. (1988). SERVQUAL: A Multiple Item Scale For Measuring Consumer Perceptions of Service Quality. Journal of Retailing, 64, 13-40.

Pitt, L., Watson, R., \& Kavan, C. (1995). Service Quality: A Measure of Information Systems Effectiveness. MIS Quarterly, 19, 173-187.

Rai, A., Lang, S., \& Welker, R. (2002). Assessing The Validity of IS Success Models: An Empirical Test and Theoretical Analysis. Information Systems Research, 13, 50-69.

Santamour, B. (2011). MYOB? It's Still Good Advice. Hospital and Health Network, $85(20), 44$

Septianita, W., Agus Winarno, W., \& Arif, A. (2014). Pengaruh Kualitas Sistem, Kualitas Informasi, Kualitas Pelayanan Rail Ticketing System (RTS) Terhadap Kepuasan Pengguna (Studi Empiris Pada PT. KERETA API INDONESIA (PERSERO) DAOP 9 JEMBER). E-Journal Ekonomi Bisnis Dan Akutansi, 1(1), 53-56. doi:https://doi.org/10.19184/ejeba.v1i1.570

Tax, S. C., \& Bowen, D. (2006). How To Prevent Your Customers From Failing. MIT Sloan Management Review, 47, 30-33.

Wijanto, S. (2008). Structural Equation Model (SEM) dengan LISREL 8.8: Konsep dan Tutorial. Yogyakarta: Graha Ilmu. 